\title{
COMPOUND GALACTOSYLCERAMIDASE GENE (GALC) HETEROZYGOSITY IN A BOY WITH INFANTILE KRABBE DISEASE (KD)
}

\author{
Zoran Gucev, Velibor Tasic
}

University Children's Hospital, Medical Faculty, Skopje, R. Macedonia

Corresponding Author: Zoran Gucev, University Children's Hospital, Medical Faculty Skopje, R. Macedonia, Phone: +389 70279 742; Mail: gucevz@gmail.com

\begin{abstract}
Krabbe disease (KD) (globoid cell leukodystrophy) is a degenerative, lysosomal storage disease, caused by a severe loss of galactocerebrosidase (GALC) enzymatic activity. The inheritance is autosomal recessive. KD affects the white matter of the central and peripheral nervous systems.

We present a 3 year old boy in whom the disease had an 'infantile' or 'classic' presentation, with spasticity, irritability, and developmental delay. In addition the boy showed progressive severe motor and mental deterioration, difficulties in swallowing and decerebration.

Molecular analysis revealed that the child is a compound heterozygote: p.Asp187Val (c.560A>T) and p.Ile250Thr $(\mathrm{c} .749 \mathrm{~T}>\mathrm{C})$. The father was the carrier of p.Asp187Val $(\mathrm{c} .560 \mathrm{~A}>\mathrm{T})$, while the mother was the carrier of the p.Ile250Thr $(\mathrm{c} .749 \mathrm{~T}>\mathrm{C})$ in exon 6 of the GALC gene.

The clinical course in this compound heterozygote is severe and the patient passed away at the age of 3 years. Genotype-phenotype relations are discussed in this Macedonian patient with KD.
\end{abstract}

Key words: Krabbe disease, infantile form, compound heterozygote.

\section{Introduction}

The infantile or classic KD is a rapidly progressive disease with severe motor and mental deterioration, decerebration and death by age 2 years $[1,2]$. However, there is a late onset form (late-infantile 6 months to 3 years, juvenile 3 to 8 years, and even adult-onset forms) in 10 to $15 \%$ of patients, with milder clinical course. Interestingly, even within families the disease severity is variable [3, 4].

We describe a compound heterozygote GALC patient with infantile form of KD.

\section{Case report}

This is a 12 month old boy, the first child of unrelated and healthy parents. The pregnancy and delivery (40 $0^{\text {th }}$ gestational week) were uneventful. Birth weight was $3370 \mathrm{~g}$, birth length $52 \mathrm{~cm}$, head circumference was not available, and the Apgar score was 9/10.
The parents noticed hypotony, the child was unable to hold his head or to seat at the age of 8 months. The feeding was difficult as the swallowing was affected. At the physical examination performed at the age of 8 months there was a significant hypotony, hyperextension of the axial muscles, the arms were in flexion, the hands clenched in fists, the legs were in a total extension with the plantar flexion, while the face was expressionless. No contact with people around him was possible.

The lumbar puncture showed normal cerebrospinal liquor without cells and with normal values of the glucose and the proteins. The electroencephalogram showed asymmetry of the background activity. The eye fundus examination was normal. The ultrasound examination of the brain, heart, kidneys was normal. The TORCH had normal values. The Amino acids in the blood were within the normal 
range. The first MRI of the brain revealed enlarged subarachnoid spaces and secondary dilatation of the third and fourth ventricle. The bilateral symmetrical hyperintense areas were also present at the periventricular white matter.

The results of $\beta$-galactocerebrosidase activity measured in the blood leukocytes revealed low values $(6 \mathrm{nmoles} / 17 \mathrm{~h} / \mathrm{mg}$ proteins (normal value: 15 to 53 ).

The molecular genetic analysis was performed in Graz, Austria. A previously described mutation p.Asp187Val [5] was found in Exon 6 of the GALC-gene and a p.Ile250Thr [6] in Exon 8 on the same GALC-genes.

His spasticity, irritability, and developmental delay progressed. In addition, the boy showed progressive severe motor and mental deterioration, difficulties in swallowing and decerebration. Ha passed away at the age of 3 years.

\section{Discussion}

The prevalence of $\mathrm{KD}$ is estimated to be about 1 in $100,000\left(1.0 \times 10^{-5}\right)$ [4]: from 0.40 in the Czech Republic to 1.35 in the Netherlands. Higher frequency of the gene was found in Sicily [7], in the Druze population [8], in two inbred communities in Israel.

The infantile or classic form is the most severe with progressive and extreme irritability and spasticity, as well as motor and mental delay [9]. The described boy had this very lethal form. The late-onset form patients have a longer course of the disease and survival into childhood and adolescence [4, 10-14]. The late form of $\mathrm{KB}$ is predominant, found in $66 \%$ [15] with the oldest observed in 84 years old woman.

Severe compound heterozygotes have been described [6, 15-17]. The phenotype genotype relation is difficult to be established. Milder phenotype was found in the missense mutations G286D (4), I66M + I289V, G270D, and L618S [18]. The G41S mutation inferred a longer disease course [15]. The location of the mutations in the $\mathrm{N}$ - or $\mathrm{C}$-terminus was more frequent in the adult-onset form, while the central domain mutations were predominantly found in the infantile form of KD [19]. About $45 \%$ of mutated alleles in patients of European origin have a $30 \mathrm{~kb}$ deletion covering exons
11-17 and inferred the classic infantile form of GLD. The late onset GLD was found with the c.857G>A (p.Gly286Asp in exon 8) mutation. There is an overlap of the measured GALC activity in blood or in skin fibroblasts between the control groups and the carriers, which renders the diagnosis challenging. Our patient was compound heterozygous with the genotype which proved to be severe: p.Asp187Val $(c .560 \mathrm{~A}>\mathrm{T})$ and p.Ile250Thr (c.749T $>$ C).

There is not a causative treatment. Chaperones are promising, while the allogeneic hematopoietic stem cell transplantation is of uncertain effect [20]. The transplantation of umbilical-cord blood in patients with infantile KD was not successful [21].

\section{REFERENCES}

1. Krabbe K. A new familial infantile form of diffuse brain-sclerosis. Brain. 1916; 39: 74-114.

2. Graziano AC, Cardile V. History, genetic, and recent advances on Krabbe disease. Gene. 2015; 555(1): 2 13.

3. Liao P, Gelinas J, Sirrs S. Phenotypic variability of krabbe disease across the lifespan. Can J Neurol Sci. 2014; 41(1): 5-12.

4. Tappino B, Biancheri R, Mort M, Regis S, Corsolini F, Rossi A, Stroppiano M, et al. Identification and characterization of 15 novel GALC gene mutations causing Krabbe disease. Hum Mutat. 2010; 31: E1894-1914.

5. Luzi P, Rafi MA, Wenger DA. Multiple mutations in the GALC gene in a patient with adult-onset Krabbe disease. Ann Neurol. 1996; 40(1): 116-9.

6. De Gasperi R, Gama Sosa MA, Sartorato EL, Battistini S, MacFarlane H, Gusella JF, Krivit W, Kolodny EH. Molecular heterogeneity of late-onset forms of globoid-cell leukodystrophy. Am J Hum Genet. 1996; 59(6): 1233-42.

7. Fiumara A, Barone R, Arena A, Filocamo M, Lissens W, Pavone L, Sorge G. Krabbe leukodystrophy in a selected population with high rate of late onset forms: longer survival linked to c.121G-A (p.gly41ser) mutation. Clin Genet. 2011; 80: 452-458.

8. Zlotogora J, Regev R, Zeigler M, Iancu TC, Bach G. Krabbe disease: increased incidence in a highly inbred community. Am J Med Genet. 1985; 21 : 765-770.

9. Wenger DA, Rafi MA, Luzi P, Datto J. CostantinoCeccarini, E. Krabbe disease: genetic aspects and progress toward therapy. Molec Genet Metab. 2000; 70: 1-9.

10. Suzuki Y, Suzuki K. Krabbe's globoid cell leukodystrophy: deficiency of galactocerebrosidase in se- 
rum, leukocytes, and fibroblasts. Science. 1971; 171: 73-74.

11. Crome L. Hanefeld F, Patrick D, Wilson J. Late onset globoid cell leucodystrophy. Brain. 1973; 96 : 841-848.

12. Phelps M, Aicardi J, Vanier MT. Late onset Krabbe's leukodystrophy: a report of four cases. J Neurol Neurosurg Psychiat. 1991; 54: 293-296.

13. Verdru P, Lammens M, Dom R, Van Elsen A, Carton H. Globoid cell leukodystrophy: a family with both late-infantile and adult type. Neurology. 1991; 41: 1382-1384.

14. Kolodny EH, Raghavan S, Krivit W. Late-onset Krabbe disease (globoid cell leukodystrophy): clinical and biochemical features of 15 cases. Dev Neurosci. 1991; 13: 232-239.

15. Fiumara A, Barone R, Arena A, Filocamo M, Lissens W, Pavone L, Sorge G. Krabbe leukodystrophy in a selected population with high rate of late onset forms: longer survival linked to c.121G-A (p.gly41ser) mutation. Clin Genet. 2011; 80: 452-458.

16. Rafi MA, Luzi P, Chen YQ, Wenger DA. A large deletion together with a point mutation in the GALC gene is a common mutant allele in patients with infantile Krabbe disease. Hum Molec Genet. 1995; 4: 1285-1289.

17. Rafi MA, Luzi P, Zlotogora J, Wenger DA. Two different mutations are responsible for Krabbe disease in the Druze and Moslem Arab populations in Israel. Hum Genet. 1996; 97: 304-308.

18. Xu C, Sakai N, Taniike M, Inui K, Ozono K. Six novel mutations detected in the GALC gene in 17 Japanese patients with Krabbe disease, and new genotype-phenotype correlation. J Hum Genet. 2006; 51: 548-554.

19. Furuya H, Kukita Y, Nagano S, Sakai Y, Yamashita Y, Fukuyama H, Inatomi Y, et al. Adult onset globoid cell leukodystrophy (Krabbe disease): analysis of galactosylceramidase cDNA from four Japanese patients. Hum Genet. 1997; 100: 450-456.

20. Krivit W, Shapiro EG, Peters C, Wagner JE, Cornu G, Kurtzberg J, Wenger DA, et al. Hematopoietic stem-cell transplantation in globoid-cell leukodystrophy. New Eng. J Med. 1998; 338: 1119-1126.

21. Escolar ML, Poe MD, Provenzale JM, Richards KC, Allison J, Wood S, Wenger DA, et al. Transplantation of umbilical-cord blood in babies with infantile Krabbe's disease. New Eng J Med. 2005; 352: 2069-2081.
Резиме

\section{КОМПАУНД ХЕТЕРОЗИГОТНОСТ НА ГЕНОТ НА ГАЛАКТОЗИЛКЕРАМИДАЗА $(G A L C)$ КАЈ ИНФАНТИЛНА БОЛЕСТ KPAБE (KD)}

\section{Зоран Гучев, Велибор Тасиќ}

Универзитетска клиника за детски болести, Медицински факултет, Скопје, Р. Македонија

Болеста на Крабе (KD) (глобоидна клеточна леукодистрофија) е дегенеративна болест на лизозомните депоа, предизвикана од тешка загуба на ензимската активност на галактозилкерамидаза (GALC). Наследувањето е автозомно рецесивно. KD ја зафаќа белата маса на централниот и на периферниот нервен систем.

Претставивме 3-годишно момче, кај кое болеста имаше инфантилна или класична презентација, со спастичност, раздразливост и доцнење во развојот. Исто така, момчето покажа и прогресивно тешко моторно и ментално заостанување, тешкотии при голтање и децеребрација.

Молекуларната анализа откри дека детето е хетерозиготно: p.Asp187Val (c.560A >T) и p.Ile250Thr (c.749T $>$ C). Таткото е носител на p.Asp187Val (c.560A>T), додека мајката е носител на p.Ile250Thr (c.749T>C) во егзонот 6 на генот GALC.

Клиничкиот тек во овој хетерозиготен комплекс е тежок и пациентот почина на возраст од 3 години. Се дискутираше за генотип фенотип односите кај овој македонски пациент со болеста Крабе.

Клучни зборови: болест Крабе, инфантилна форма, комплексен хетерозигот 